\title{
Prevalence of Some Deteriorating Microorganisms in Some Varieties of Cheese
}

\author{
Ayah B. Abdel-Salam, Neveen S. M. Soliman \\ Department of Food Hygiene and Control, Faculty of Veterinary Medicine, Cairo University, Giza, Egypt \\ Email: neveensoliman22@yahoo.com
}

How to cite this paper: Abdel-Salam, A.B. and Soliman, N.S.M. (2019) Prevalence of Some Deteriorating Microorganisms in Some Varieties of Cheese. Open Journal of Applied Sciences, 9, 620-630. https://doi.org/10.4236/ojapps.2019.97050

Received: June 14, 2019

Accepted: July 27, 2019

Published: July 30, 2019

Copyright $\odot 2019$ by author(s) and Scientific Research Publishing Inc. This work is licensed under the Creative Commons Attribution International License (CC BY 4.0).

http://creativecommons.org/licenses/by/4.0/

\section{(c) (i) Open Access}

\begin{abstract}
Aim: This work throws light on the deteriorating microorganisms in some varieties of cheeses [hard cheese (Ras cheese), and processed cheese]. Material and Method: Thirty Ras cheese and processed cheese samples were collected randomly and subjected to chemical \& microbiological examination to determine its contamination with deteriorating microorganisms. Results: Chemical examination showed that the mean titratable acidity \% of Ras and Processed cheese samples were $0.5 \pm 0.073$ and $0.93 \% \pm 0.062 \%$, respectively, while salt $\%$ were $3.4 \pm 0.078$ and $1.03 \% \pm 0.05 \%$, respectively. Most of samples were contaminated with high numbers of Coliforms, yeast, mold, proteolytic, lipolytic and Enterococci. Conclusion: There are poor hygienic measures during production, processing and handling of cheese.
\end{abstract}

\section{Keywords}

Titratable Acidity, Salt, Proteolytic Microorganisms, Coliforms, Enterococci

\section{Introduction}

Dairy food spoilage varies according to food type, microbial type and numbers that cause changes in color, odor and texture with sliminess, gas and liquid accumulation, microorganisms must multiply and reach "spoilage detection level". According to the nature of spoilage and types of microbes, the spoilage detection level can range from $10^{6}-10^{8}$ cells $/ \mathrm{g}$ or $/ \mathrm{ml}$.

Spoilage microorganisms include psychrotrophic bacteria, yeast, mold, hetero fermentative lactobacilli, and spore-forming bacteria. Psychrotrophic bacteria produce extracellular hydrolytic enzymes, and contamination of pasteurized products with these bacteria affect their shelf life. Fungal spoilage of dairy foods is manifested by the presence of a wide variety of metabolic by-products, causing off-flavors, and changes in color or texture. Coliforms, yeast, hetero fermentative lactic acid bacte- 
ria and spore-forming bacteria cause gas defects in cheese. There are a wide variety of spoilage microorganisms in dairy foods due to practices used in production, formulation, processing, packaging, storage, distribution, and handling [1].

Fermentation of lactose lower $\mathrm{pH}$ acts as a preservative and allows desirable microflora to restrict undesirable microorganisms growth; adding salt to reduce the water activity (aw); packaging with less oxygen and freezing slow spoilage rate of dairy foods [1].

This work was planned to throw light on the deteriorating microorganisms in some varieties of cheeses [hard cheese (Ras cheese), processed cheese].

\section{Material and Methods}

\subsection{Sample Collection}

Thirty each of hard cheese (Ras), and processed cheese was randomly collected as sold to consumers from dairy shops in Cairo and Giza governorates.

\subsection{Chemical Examination}

Titratable acidity percentage was measured according to [2] and $\mathrm{NaCl}$ content according to Volhard method [3].

\subsection{Microbiological Examination}

Preparation of decimal dilutions for the collected samples, Total coliform count with Completed test for E. coli, Total proteolytic count, Lipolytic microorganisms count, Enterococci count, Total Yeast and Total Mold count were examined according to [3] with bio chemical identification of the isolated Coliforms \& Enterococci species were examined according to [4]. While yeast species were examined according to [5].

\section{Results and Discussion}

\subsection{Chemical Examination}

Titratable acidity percentage: Increase of titratable acidity is a monitor of freshness and the bacterial activity in milk [1] [6]. While lower $\mathrm{pH}$ of milk to less than 4.6 protects the fermented dairy products from contamination with pathogens and considers safe hygienically [7] [8]. Data recorded in Table 1 showed that the mean titratable acidity percentage of the examined Ras and Processed cheese samples were $0.5 \pm 0.073$ and $0.93 \% \pm 0.062 \%$, respectively. Nearly similar

Table 1. Statistical analytical results of titratable acidity \% \& salt \% in the examined samples.

\begin{tabular}{ccccc}
\hline & Total No. of samples & Min. & Max. & Mean \pm S.E.M. \\
\hline $\begin{array}{c}\text { Titratable acidity } \\
\text { percentages }\end{array}$ & Ras cheese & 0.3 & 0.93 & $0.5 \pm 0.073$ \\
\multirow{2}{*}{$\begin{array}{c}\text { Salt percentages } \\
\text { Processed cheese }\end{array}$} & 0.46 & 1.7 & $0.93 \pm 0.062$ \\
& Ras cheese & 2.8 & 4.7 & $3.4 \pm 0.078$ \\
\hline
\end{tabular}


findings of Ras cheese were obtained by [9]. Higher results of processed cheese were reported by [10]. Whereas, lower findings of Processed cheese were obtained by [9] [11].

Salt percentage: Salt added is an important step in most cheese varieties; it enhances flavor, draws the whey out of the curd and controls the undesirable microorganisms. The salt content of cheese ranges from about $0.5 \%$ to $0.7 \%(\mathrm{w} / \mathrm{w})$ in acid curd varieties, such as cottage cheese to about $4 \%$ to $6 \%(\mathrm{w} / \mathrm{w})$ in pickled cheeses [12] [13]. Regarding the salt percentage in examined cheese samples (Table 1), it ranged from $2.8-4.7$ and $0.51-1.4$ with a mean value of $3.4 \pm 0.078$ and $1.03 \% \pm 0.05 \%$ in the examined samples of Ras cheese and Processed cheese, respectively. Nearly similar results in processed cheese were recorded by [9] While lower obtaining of Ras cheese were recorded by [9].

The variation of salt content in the examined cheese samples is due to the added salt depends on individual dairies, and there is no standard in addition of salt to cheese and the amount of salt relies on discretion of cheese maker [12]. The high salt content in some examined samples can mask the poor bacteriological quality of the raw milk and prevent gas holes formation and off-flavor especially in summer [14].

\subsection{Microbiological Examination}

Coliforms contents (MPN/g): Coliform count is an indicator of possible fecal contamination, microbial quality and reflects the hygienic conditions in the food processing [15]. Regarding the results represented in Table 2, coliform could be detected in all of the examined samples of Ras cheese and Processed cheese, with mean values of $1.2 \times 10^{10} \pm 3.3 \times 10^{9}$ and $2.5 \times 10^{9} \pm 6.5 \times 10^{8}$ MPN/g in Ras and Processed cheese, respectively.

Lower results of processed cheese were reported by [9] [16] [17]. Lower results

Table 2. Statistical analytical results of the microbiological parameters in the examined cheese samples.

\begin{tabular}{ccccccc}
\hline & Total No. of samples & \multicolumn{2}{c}{ Positive samples } & Min. & Max. & Mean \pm S.E.M. \\
\cline { 3 - 4 } & & No. & $\%$ & & & \\
& Ras cheese & 30.0 & 100.0 & $2.5 \times 10^{8}$ & $1.2 \times 10^{11}$ & $1.2 \times 10^{10} \pm 3.3 \times 10^{9}$ \\
$\begin{array}{c}\text { Coliform count } \\
\text { (MPN/g.) }\end{array}$ & Processed cheese & 30.0 & 100.0 & $9 \times 10^{6}$ & $1.3 \times 10^{10}$ & $2.5 \times 10^{9} \pm 6.5 \times 10^{8}$ \\
Total proteolytic count & Ras cheese & 30.0 & 100.0 & $120 \times 10^{5}$ & $7.4 \times 10^{11}$ & $5.8 \times 10^{10} \pm 4.5 \times 10^{10}$ \\
(cfu/g) & Processed cheese & 18.0 & 60.0 & 150.0 & $3.4 \times 10^{7}$ & $6.3 \times 10^{6} \pm 2.8 \times 10^{6}$ \\
Total lipolytic count (cfu/g) & Ras cheese & 30.0 & 100.0 & $10^{3}$ & $4.8 \times 10^{9}$ & $3.0 \times 10^{8} \pm 1.2 \times 10^{8}$ \\
& Processed cheese & 12.0 & 40.0 & 110.0 & $5.7 \times 10^{4}$ & $16.8 \times 10^{3} \pm 5.4 \times 10^{3}$ \\
Enterococci count (cfu/g) & Ras cheese & 30.0 & 100.0 & $7 \times 10^{3}$ & $8.8 \times 10^{9}$ & $7.7 \times 10^{8} \pm 7.2 \times 10^{8}$ \\
Total yeast count & Processed cheese & 30.0 & 100.0 & $15 \times 10^{3}$ & $67 \times 10^{9}$ & $4.3 \times 10^{8} \pm 2.7 \times 10^{8}$ \\
(cfu/g.) & Ras cheese & 30.0 & 100.0 & $6 \times 10^{3}$ & $1.1 \times 10^{8}$ & $4.9 \times 10^{7} \pm 5.6 \times 10^{6}$ \\
Total mold count & Processed cheese & 25.0 & 83.3 & 300.0 & $3.1 \times 10^{4}$ & $2.57 \times 10^{5} \pm 1.8 \times 10^{5}$ \\
(cfu/g.) & Ras cheese & 10.0 & 33.3 & $5 \times 10^{3}$ & $4 \times 10^{6}$ & $3.6 \times 10^{5} \pm 2.5 \times 10^{5}$ \\
\hline
\end{tabular}


of Ras cheese were reported by [9] [17]. The results revealed that all of the examined Ras cheese and processed cheese contain high numbers of coliform. Egyptian Standards recommend the count should be less than 10 cells/g [15], the obtained results makes these cheeses of bad quality and cause losses economically [18].

Isolated coliforms: Biochemical identification of Coliform organisms in Ras cheese, results revealed that Enterobacter intermedius (37.1\%) was the most frequent one followed by Citrobacter diversus (16.13\%), Citrobacter freundii (12.9\%) and Klebsiella oxytoca (11.29\%), while E. coli could be detected only in one isolate. Enterobacter intermedius (21.43), E. coli (20\%) \& Citrobacter freundii (20\%) had the highest incidence, then Klebsiella oxytoca (12.86\%), Citrobacter diversus (11.4\%) and Erwinia chrysanthemi (7.14\%) in the examined Processed cheese (Table 3).

E. coli was found in Ras cheese and processed cheese with percentages of 1.61 and $20 \%$, respectively. E. coli is due to fecal contamination, indicates that other pathogens of fecal origin may be found [19]. Results presented in Table 4 illustrated the serological identification of the suspected isolates of $E$. coli by slide agglutination test. In Ras cheese, the suspected isolates were negative, while in processed cheese one strain out of 14 strains was positive and classified as E. coli $\mathrm{O}_{25}$. Escherichia coli is present in the gastrointestinal tract of man and dairy animals. Milk can be contaminated either directly through animal feces or indirectly through contaminated surrounding environment, workers, and equipments. Most strains of E. coli are harmless commensals; some causes human gastrointestinal disease with mild to severe symptoms that may be fatal in high-risk individuals. Moreover, E. coli was reported for cases of pyelonephritis cystitis, pyelitis, peritonitis and appendicitis [20] [21].

Total yeast count: Yeast contamination is economically hazard as it causes

Table 3. Incidence of isolated coliforms from the examined samples.

\begin{tabular}{ccccc}
\hline \multirow{2}{*}{ Isolated Coliform } & \multicolumn{2}{c}{ Ras cheese } & \multicolumn{2}{c}{ Processed cheese } \\
\cline { 2 - 5 } Citrobacter diversus & No. & $\%$ & No. & $\%$ \\
Citrobacter freundii & 10.0 & 16.13 & 8.0 & 11.4 \\
E. coli & 8.0 & 12.9 & 14.0 & 20.0 \\
Enterobacter aerogenes & 1.0 & 1.61 & 14.0 & 20.0 \\
Enterobacter cloaca & 2.0 & 3.23 & 0.0 & 0.0 \\
Enterobacter intermedius & 0.0 & 0.0 & 0.0 & 0.0 \\
Erwinia chrysanthemi & 23.0 & 37.1 & 15.0 & 21.43 \\
Klebsiella oxytoca & 4.0 & 6.45 & 5.0 & 7.14 \\
Klebsiella pneumoniae subsp. ozaenae & 0.0 & 11.29 & 9.0 & 12.86 \\
Serratia fonticola & 7.0 & 0.0 & 0.0 & 0.0 \\
Serratia rubidaea & 4.0 & 6.45 & 3.0 & 4.3 \\
Total & 3.0 & 4.84 & 2.0 & 2.88 \\
\hline
\end{tabular}


Table 4. Serological identification of suspected $E$. coli isolates by slide agglutination test.

\begin{tabular}{cccccc}
\hline \multirow{2}{*}{ Type of sample } & \multicolumn{2}{c}{ No. of suspected $E$. coli } & \multicolumn{3}{c}{ Slide agglutination test } \\
\cline { 2 - 6 } & No. & $\%$ & ve+ & $\%$ & Serotype \\
\hline Ras cheese & 1 & 1.61 & 0.0 & 0.0 & - \\
Processed cheese & 14 & 20 & 1.0 & 25.0 & $\mathrm{O}_{25}$ \\
\hline
\end{tabular}

objectionable changes as yeasty flavor and frothy consistency. Some species of yeast cause public hazard as endocarditis, gastrointestinal disturbance, and sometimes, fatal systemic diseases [22]. Data in Table 2 revealed that contaminated yeast could be detected in $30(100 \%)$ and $25(83.3 \%)$ of Ras cheese and Processed cheese, respectively, with mean values of $4.9 \times 10^{7} \pm 5.6 \times 10^{6}$ and $2.57 \times 10^{5} \pm$ $1.8 \times 10^{5} \mathrm{cfu} / \mathrm{g}$, respectively. Nearly similar results of Ras cheese were recorded by [9] [17], while lower findings were recorded by [23]. Lower results of Processed cheese were obtained by [11] [24], while higher results were recorded by [9] [17]. According to the Egyptian standards the count of total viable yeast should not exceed $100 \mathrm{cfu} / \mathrm{g}$ in hard cheese [25], 100\% of Ras cheese samples was disagreed with this standard. This high level may be due to poor hygienic measures during production or using raw materials of bad quality [26].

Isolated yeast species: from Figure 1, the obtained results of cheese proved that $C$. albicans, C. diddensiae; $C$. intermedia; C. mesenterica; C. parapsilosis, $C$. zeylanoides; Cryptococcus curvatus, Debaryomyces hansenii; Db. Accidentalis, Filobasidiumcapsuligenum; Gal. Geotrichum; Geo. fermentans, Kluyveromyces marxianus, Lachanceacidri, Leucosporidiumscottii, P. guilliermondit; Schizosaccharomyces pombe, $\mathcal{S}$ copsisvini and Zygoascushellenicus were isolated from the examined samples of Ras cheese with concern that Gal. geotrichum (16.98\%) and Schizosaccharomyces pombe (15.09\%) had the highest incidence among the isolated strains. On Processed cheese, $C$. albicans (13.34\%) was the most frequent one then Schizosaccharomyces pombe (11.13\%); C. catenulate (6.67\%); Cryptococcus curvatus (6.67\%); Kluyveromyces marxianus (6.67\%) and Lipomyces lipofer $(6.67 \%)$. High acidity, low moisture content, storage at low temperature, and high salt concentration enhance growth of yeast. These spoilage yeast cause gas production, discoloration, soften texture, and fruity, bitter or yeasty off flavors [27] [28]. Candida spp. are the most common fungal infection in immune compromised persons known as candidiasis, which caused by C. albicans [29] [30].

Total mold count: Presence of mold cause economic losses because it is accompanied by visible spoilage discoloration, off flavor, and rejection of the product, and may be a source of mycotoxins result in outbreaks of human food poisoning and many diseases as cancer, leukemia, and kidney toxicity [31] [32]. Regarding the data recorded in Table 2 mold was present in 33.3\% and 56.67\% of the examined Ras cheese and Processed cheese samples, respectively, The counts were ranged from $5 \times 10^{3}-4 \times 10^{6}$ and $200-10^{7} \mathrm{cfu} / \mathrm{g}$, with mean values of $3.6 \times 10^{5} \pm 2.5 \times 10^{5}$ and $6.7 \times 10^{5} \pm 6.2 \times 10^{5} \mathrm{cfu} / \mathrm{g}$, respectively. Nearly similar 


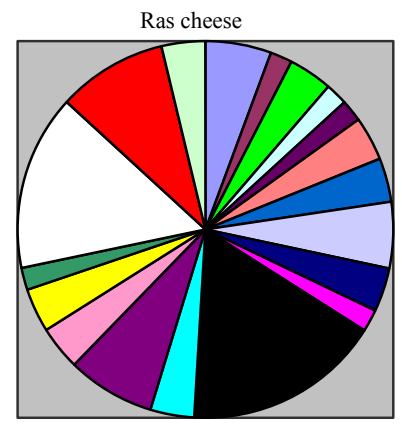

Processed cheese

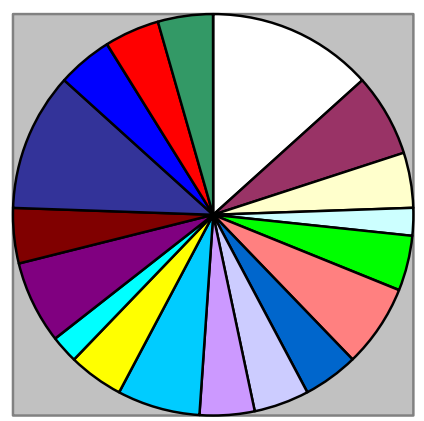

\begin{tabular}{|ll|}
\hline$\square$ C. albicans & $\square$ C. diddensiae \\
$\square$ C. intermedia & $\square$ C. mesenterica \\
C. parapsilosis & $\square$ C. zeylanoides \\
$\square$ Cryptococcus curvatus & $\square$ Debaryomyces hansenii \\
$\square$ Db. Accidentalis & $\square$ Filobasidium capsuligenum \\
$\square$ Gal. geotrichum & $\square$ Geo.fermentans \\
$\square$ Kluyveromyces marxianus & $\square$ Lachancea cidri \\
$\square$ Leucosporidium scottii & $\square$ P.guilliermondii \\
$\square$ Schizosaccharomyces pombe & $\square S^{\prime}$ copsis vini \\
$\square$ Zygoascus hellenicus & \\
\hline
\end{tabular}

\begin{tabular}{|c|}
\hline 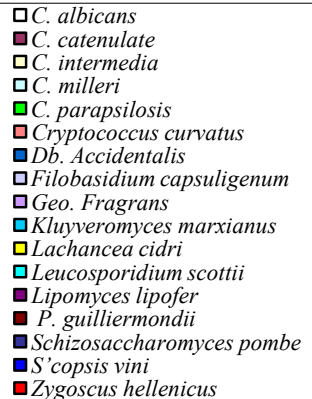 \\
\hline
\end{tabular}

Figure 1. Incidence of isolated yeast from the examined sample.

findings of Processed cheese were reported by [9] [17], while Lower results of Processed cheese were recorded by [23] [24]. Nearly similar findings of Ras cheese were recorded by [17]. Higher obtaining of Ras cheese was recorded by [9], while lower outcomes were reported by [23]. It was found that 33.3 and $56.67 \%$ of the examined Ras cheese and Processed cheese, respectively were highly contaminated with mold and disagree with the Egyptian standards [15] [33] because of the warm weather and inadequate refrigeration, increased species diversity [34]. The fungi contributed to poor cleaning and unhygienic measures during production and handling and post processing contamination [35] [36].

Total proteolytic count: Bacillus spp. can survive heat treatment of milk [37] [38]. They can produce thermo stable hydrolytic enzymes are produced by Bacillus spp [39] [40]. B. stearothermophilus, B. licheniformis, B. coagulans, B. cereus, $B$. subtilis and $B$. circulansare the most commonly isolated species. Moreover, Bacillus species such as $B$. cereus, B. licheniformis and B. subtilis can produce many types of toxins associated with food borne diseases [41] [42]. The proteolytic enzymes may cause undesirable changes in texture [25] [43] and in flavor (especially bitterness). According to the obtained results in (Table 2) it was cleared that proteolytic organisms were present in 30 (100\%) and 18 (60\%) of the examined Ras cheese and Processed cheese, with a mean count of $5.8 \times$ $10^{10} \pm 4.5 \times 10^{10}$ and $6.3 \times 10^{6} \pm 2.8 \times 10^{6} \mathrm{cfu} / \mathrm{g}$, respectively. Lower results of Ras $\&$ Processed cheese were obtained by [11] [44].

Total lipolytic count: Psychrophilic bacteria like Pseudomonas, Enterobacter, Alcaligenes and some spore-formers produce extracellular lipase enzyme 

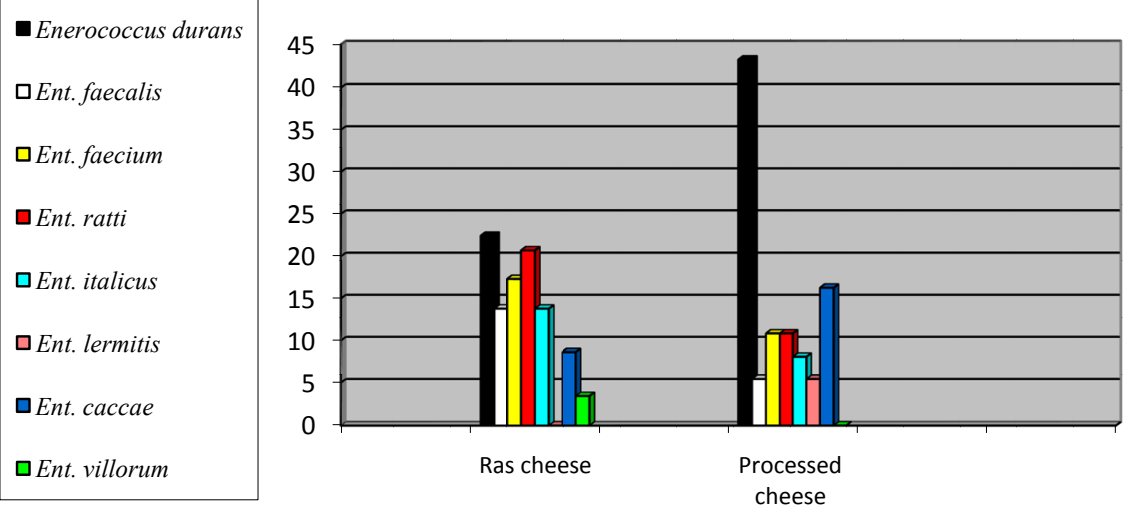

Figure 2. Incidence of isolated Enterococci from the examined cheese sample.

that is adsorbed on milk fat globules and concentrated in the manufactured cheese. These enzymes hydrolyze triglyceride fat constituents of short chain fatty acids, including butyric, caproic, caprylic, and capric acids resulting in unpleasant odors in milk and rancidity in cheese [39] [45]. Results detected in Table 2 revealed that lipolytic organisms were present in Ras and Processed cheese samples in percentages of $100 \%$ and $40 \%$, respectively, with a mean count of $3 \times 10^{8}$ $\pm 1.2 \times 10^{8}$ and $16.8 \times 10^{3} \pm 5.4 \times 10^{3} \mathrm{cfu} / \mathrm{g}$, respectively. Lower results of Ras \& Processed cheese were obtained by [11] [44].

Total Enterococci count: Enterococci are useful indicator to the hygienic conditions during food manufacture. The presence of specific virulence factors in some strains of Enterococcus faecalis and to a lesser extent in strains of Enterococcus faecium makes them pathogenic to human [46] [47]. Using contaminated water supply, equipment and unhygienic conditions during the production, handling, and milk processing are the causes for their presence [48] [49] [50]. The given results recorded in Table 2 illustrated that Enterococci were isolated from all examined cheese samples with a mean value of $7.7 \times 10^{8} \pm 7.2 \times$ $10^{8}$ and $4.3 \times 10^{8} \pm 2.7 \times 10^{8} \mathrm{cfu} / \mathrm{g}$ in the examined Ras and Processed cheese samples, respectively. Lower results of Ras cheese were recorded by [17]. Nearly similar findings of processed cheese were recorded by [17], whereas lower results were recorded by [51].

Isolated Enterococci: The biochemical identification of Enterococci isolates in the examined cheese samples showed that Ent. durans (22.42\%), Ent. ratti (20.69\%) and Ent. faecium (17.24\%) had the highest incidence, then Ent. faecalis (13.79\%), Ent. italicus (13.79\%) and Ent. caccae (8.63\%) in the examined Ras cheese samples. Ent. durans was the most frequent one in processed cheese samples, followed by Ent. caccae (16.22\%), Ent. faecium (10.81\%), Ent. ratti (10.81\%) and Ent. italicus (8.1\%) (Figure 2).

Some enterococci of dairy origin have been recorded to the production of bacteriocins (enterocins) which has inhibitory effect to some pathogenic bacteria (Listeria monocytogenes and Salmonella spp.) [52]. Some studies have reported that $E$. faecium and $E$. faecalis may be a potential recipient of vancomycin resistance genes, so, [49] has recommended that E. faecium should not be considered 
as probiotics for human use. Also, Enterococci are pathogens causing endocarditis, bacteraemia, and urinary tract infections [16].

\section{Conflicts of Interest}

The authors declare no conflicts of interest regarding the publication of this paper.

\section{References}

[1] Sorhaug, T. and Stepaniak, L. (1997) Psychrotrophs and Their Enzymes in Milk and Dairy Products: Quality Aspects. Trends in Food Science \& Technology, 8, 35-41. https://doi.org/10.1016/S0924-2244(97)01006-6

[2] Association of Official Analytical Chemists "AOAC" (2000) Official Methods of Analysis of AOAC International. 17th Edition, AOAC International, Rockville.

[3] American Public Health Association "APHA" (2004) Standard Methods for Examination of Dairy Products. 17th Edition, American Public Health Association, Washington DC.

[4] Egyptian Standard (999-2/2005) A: Processed Cheese Specification, Egyptian Organization for Standardization (EOS) and Quality Control. Ministry of Industry, Cairo.

[5] Tayseer, A.S., Mohamed, O.M., Nissreen, H.M. and Haifa, M.O. (2011) Chemical and Microbiological Evaluation of Processed Cheese Available in Khartoum Market, Sudan. American Journal of Food and Nutrition, 1, 28-33. https://doi.org/10.5251/ajfn.2011.1.1.28.33

[6] Nutting, G., Lomatt, S. and Barber, F. (2009) Estimation of Coliform Bacteria in Ice-Cream. Journal of Applied Microbiology, 7, 196-199.

[7] Al-Kadamany, E., Toufeili, I., Khattar, M., Abou-Jawdeh, Y., Harakeh, S. and Haddad, T. (2001) Determination of Shelf Life of Concentrated Yoghurt (Labenah) Produced by In-Bag Straining of Set Yoghurt Using Hazard Analysis. Journal of Dairy Science, 85, 1023-1030. https://doi.org/10.3168/jds.S0022-0302(02)74162-3

[8] Westall, S. and Filtenborg, O. (2010) Yeast Occurrence in Danish Feta Cheese. Journal of Food Microbiology, 15, 215-222.

[9] Hidalgo, H. (2011) Candidiases. Internal Medicine Journal, 88, 52-58.

[10] Karakaş, R. and Korukluoğlu, M. (2006) A Traditional Cheese: Microbiological and Chemical Properties of Sepet Cheese. GIDA/ The Journal of Food, 31, 169-172.

[11] Svensson, B., Ekelund, K., Ogura, H. and Christiansson, A. (2004) Characterization of Bacillus cereus Isolated from Milk Silo Tanks at Eight Different Dairy Plants. International Dairy Journal, 14, 17-27. https://doi.org/10.1016/S0958-6946(03)00152-3

[12] Giraffa, G. (2003) Functionality of Enterococci in Dairy Products. International Journal of Food Microbiology, 88, 215-222. https://doi.org/10.1016/S0168-1605(03)00183-1

[13] Mennane, Z., Faid, M., Lagzouli, M., Ouhssine, M., Elyachioui, M., Berny, E., Ennouali, M. and Khedid, K. (2007) Physico-Chemical, Microbial and Sensory Characterization of Moroccan Klila. Middle-East Journal of Scientific Research, 2, 93-97.

[14] International Committee on Microbiological Specifications for Foods (ICMSF) (1982) Microorganism in Food-Their Significance and Methods of Enumeration. 
2nd Edition, Univ. of Toronto Press, Toronto, Buffalo and London.

[15] Turkoglu, H., Ceylan, Z. and Dayisoylu, K. (2003) The Microbiological and Chemical Quality of Orgu Cheese Produced in Turkey. Pakistan Journal of Nutrition, 2, 95-97. https://doi.org/10.3923/pjn.2003.92.94

[16] Esraa, A.G. (2012) Microbiological Evaluation of Soft Cheeses Sold in Beni-Suef Markets. PhD Thesis, Beni Suef University, Cairo.

[17] Aya, B.A. (2014) Prevalence of Biological Hazards in Milk and Some Dairy Products in Egyptian Markets. PhD Thesis, Beni Suef University, Cairo.

[18] Hussein, F.S., El Zubeir, I.M. and Fadlelmoula, A.A. (2011) Quality Evaluation of Imported and Locally Produced Processed Cheese in Sudan. Jordan Journal of Biological Sciences, 4, 231-235.

[19] Sert, D., Ayar, A. and Akin, N. (2007) The Effects of Starter Culture on Chemical Composition, Microbiological and Sensory Characteristics of Turkish Kasar Cheese during Ripening. Internet Journal of Food Safety, 9, 7-13. https://doi.org/10.1111/j.1471-0307.2007.00339.x

[20] Nour El Dian, M.S.A. and El Zubeir, I.E.M. (2010) Chemical Composition of Processed Cheese Using Sudanese White Cheese. Research Journal of Animal and Veterinary Sciences, 5, 31-37.

[21] Desmarchelier, P. and Fegan, N. (2011) Pathogens in Milk Escherichia coli. In: Fuquay, J.W., Ed., Encyclopedia of Dairy Sciences, Elsevier, Amsterdam, 60-66. https://doi.org/10.1016/B978-0-12-374407-4.00393-9

[22] Jane, M.B. (2010) Microbiological, Physico-Chemical and Sensory Quality Aspects of Dairy Desserts Manufactured from Cottage Cheese. M.Sc. Thesis, Faculty of Natural and Agricultural Sciences, University of Pretoria, Pretoria.

[23] Ekram, E.B. and Ibtisam, E.M. (2011) Chemical Composition and Microbial Load of Set Yoghurt from Fresh and Recombined Milk Powder in Khartoum State, Sudan. International Journal of Dairy Science, 6, 172-180. https://doi.org/10.3923/ijds.2011.172.180

[24] Salwa, A., Farag, D. and Galal, E. (2012) Effect of Gamma Irradiation on the Quality and Safety of Egyptian Kariesh Cheese. The Journal of American Science, 8, 761-766.

[25] Ercan, D., Korel, F., Yüceer, Y. and Kınık, O. (2011) Physicochemical, Textural, Volatile, and Sensory Profiles of Traditional Sepetcheese. Journal of Dairy Science, 94, 4300-4312. https://doi.org/10.3168/jds.2010-3941

[26] Vanderzant, C. and Splittstoesser, D. (2005) Compendium of Methods for the Microbiological Examination of Foods. 3rd Edition, APHA Technical Committee on Microbiological Methods for Foods.

[27] Varnam, V.H. and Sutherland, P. (2009) Milk and Milk Products Series. 2nd Edition, Academic Press, London, 200-223.

[28] Eman, A.H. (2012) Assessment of Hygienic Status of Raw Milk and Some Dairy Products. M.Sc. Thesis, Damanhour University, Damanhour.

[29] Warsama, L.M., Ibtisam, E.E. and El Owni, O.A. (2006) Composition and Hygienic Quality of Sudanese Soft Cheese in Khartoum North (Sudan). International Journal of Dairy Science, 1, 36-43.

[30] Hassan, G.M. and Afify, S.I. (2007) Occurrence of Some Pathogenic Microorganisms in Kariesh Cheese and Their Public Health Significance. Beni-Suef Veterinary Med J, 142-150.

[31] Bullerman, L.B. (1980) Incidence of Mycotoxic Molds in Domestic and Imported 
Cheeses. Journal of Food Safety, 2, 47-58. https://doi.org/10.1111/j.1745-4565.1980.tb00390.x

[32] Popescu, A. and Angel, E. (2009) Analysis of Milk Quality and Its Importance for Milk Processors. Lucrări Ştiinţifice Zootehnie ŞiBiotehnologii, 42, 501-503.

[33] Egyptian Standard (1007-1/2005) B: Hard Cheese Specification, Egyptian Organization for Standardization (EOS) and Quality Control. Ministry of Industry, Cairo.

[34] Montagna, M., Erroi, R., Sanapo, S., Caggiano, G., Bagordo, F. and de Donno, A. (1998) Food Products and Fungal Contamination. Note I. Preliminary Investigation in Commercial Yoghurt. Journal of Preventive Medicine and Hygiene, 39, 68-70.

[35] Mohamed, I.H. and Mahgoub, S.A. (2013) Microbiological Characterization of the Egyptian Soft White Cheese and Identification of Its Dominant Yeasts. African Journal of Microbiology Research, 7, 2205-2212. https://doi.org/10.5897/AJMR2013.5368

[36] ELbagory, A.M., Amal, M.E., Hammad, A.M. and Salwa, A.D. (2014) Prevalence of Fungi in Locally Produced Cheese and Molecular Characterization of Isolated Toxigenic Molds. Benha Veterinary Medical Journal, 27, 9-20.

[37] Kheir, S.E.O., El Owni, O.A.O. and Abdalla, M.O.M. (2011) Comparison of Quality of Sudanese White Cheese (Gibnabayda) Manufactured with Solanum dubium Fruit Extract and Rennet. Pakistan Journal of Nutrition, 10, 106-111.

[38] Sonia, A. and Metwalli, A. (2011) Extended Shelf Life of Kariesh Cheese by Natural Preservatives. Egyptian Journal of Agricultural Research, 89, 639-649.

[39] Chen, L., Coolbear, T. and Daniel, R. (2003) Detection and Impact of Protease and Lipase Activities in Raw Milk and Milk Powders. International Dairy Journal, 13, 255-275. https://doi.org/10.1016/S0958-6946(02)00171-1

[40] Chen, L., Coolbear, T. and Daniel, R. (2004) Characteristics of Proteinases and Lipases Produced by Seven Bacillus sp. Isolates from Milk Powder Production Lines. International Dairy Journal, 14, 495-504. https://doi.org/10.1016/j.idairyj.2003.10.006

[41] Sperber, W.H. and Doyle, M.P. (2009) Compendium of the Microbiological Spoilage of Foods and Beverages, Food Microbiology and Food Safety. Springer Science-Business Media, Berlin. https://doi.org/10.1007/978-1-4419-0826-1

[42] Salih, Ö., Filiz, Y. and Cihat, O. (2010) Determination of Microbiological Characteristics of Turkish Karin Kaymagi Cheeses Packaged in Different Materials. African Journal of Microbiology Research, 4, 716-721.

[43] Dzwolak, W. and Ziajka, S. (1997) Zasady i wdrażanie HACCP w przemyśle mleczarskim. Materiały szkoleniowe. ITM ART, Olsztyn.

[44] Karima, M.F. (2012) Detection of Food Safety Hazards in Milk and Some Dairy Products. M.Sc. Thesis, Faculty of Veterinary Medicine, Cairo University, Cairo.

[45] Dogan, B. and Boor, K. (2003) Genetic Diversity and Spoilage Potentials among Pseudomonas spp. Isolated from Fluid Milk Products and Dairy Processing Plants. Applied and Environmental Microbiology, 69, 130-138. https://doi.org/10.1128/AEM.69.1.130-138.2003

[46] Laukova, A. and Vlaemynck, G. (2003) Use of Bacterion Preparation with Antimicrobial Activity in Saint-Paulin Cheese. Bulletin of the Veterinary Institute in Pulawy, 47, 497-505.

[47] Cariolato, G., Andrighetto, C. and Lombardi, A. (2008) Occurrence of Virulence Factors and Antibiotic Resistances in Enterococcus faecalis and Enterococcus faecium Collected from Dairy and Human Samples in North Italy. Food Control, 19, 
886-892. https://doi.org/10.1016/j.foodcont.2007.08.019

[48] FAO/WHO (2001) Report of a Joint FAO/WHO Expert Consultation on Evaluation of Health and Nutritional Properties of Probiotics in Food Including Powder Milk with Live Lactic Acid Bacteria. Còrdoba, 1-33.

[49] Giraffa, G. (2002) Enterococci from Foods. FEMS Microbiology Reviews, 26, 163-171. https://doi.org/10.1111/j.1574-6976.2002.tb00608.x

[50] Donnelly, C.W. (2004) Growth and Survival of Microbial Pathogens in Cheese. In: Fox, P.F., et al., Eds., Cheese: Chemistry, Physics and Microbiology, Elsevier, Amsterdam, 541-559. https://doi.org/10.1016/S1874-558X(04)80081-2

[51] Metwally, B.N. (2006) Hygienic Quality of Soft Cheese Marketed in Cairo. M.Sc. Thesis, Faculty of Veterinary Medicine, Cairo University, Cairo.

[52] Kumarsan, G., Annalvilli, R. and Sivakumar, K. (2007) Psychrotrophic Spoilage of Raw Milk at Different Temperatures of Storage. Journal of Applied Science Research, 3, 1383-1387. 